Discourse and Communication for Sustainable Education, vol. 8, no. 1, pp. 81-89, 2017

\title{
Motivation of Civic Education Teachers-in-Training in the Field of Education for Sustainable Development
}

\author{
Katharina Hiller and Barbara Reichhart \\ University of Augsburg, Germany
}

\begin{abstract}
The objective of teacher-training at university for political science is the development of professional competencies that enable teachers-in-training to act proficiently in all aspects of civic education. Although there are some studies that focus on civic education for teachers' professional competencies, most of them relate to general capability and do not concern certain significant topics. Empirical results related to the definitive topics within civic education are scarce, particularly in the field of sustainable development. Questions arise regarding teacher-training where it relates to high self-efficacy and interest within the field of civic education compared to other subjects, based on the model of political competence by Detjen and colleagues. In this article, we present the results of a quasi-experimental trial with civic education teachers-in-training ( $\mathrm{N}=108)$. Results indicate that their self-efficacy in the field of sustainable development is low compared to other areas, although there is no significant difference in their level of interest in sustainable development compared to other topics.
\end{abstract}

Keywords: civic education, civic education for sustainable development, teachers' professional competencies, teachers' motivation and interests, teachers' self-efficacy, competency model.

\section{Motivation as Part of Teachers' Professional Teaching Competencies}

Based on the model of professional competency that enables teachers to act in a professional manner (Baumert, \& Kunter, 2006), motivation is considered an essential component of teachers' professionality besides other constructs like professional knowledge, self-regulatory skills and beliefs. The model indicates that self-efficacy and interest are important parts of a teacher's professionality. Teacher self-efficacy is the teacher's confidence in his or her ability to support students' learning and growth despite other challenges (Schwarzer, \& Jerusalem, 2002). Teacher interest describes a relatively stable, content-specific construct associated with a better reference value and an epistemic orientation (Schiefele, 1974). In both national and international studies, self-efficacy and interest in teaching are found to influence teacher competency. Teachers with high levels of self-efficacy are more content with their job and demonstrate a more proactive attitude. This suggests that high self-efficacy also operates like a cushion against work- 
related stress (Gebauer, 2013; Caprara et. al., 2006). Additionally, teachers with a strong interest in their subject show more professional resilience and motivation to further develop their abilities (Eren, 2012; Retelsdorf et. al., 2010). As mediated by teachers, self-efficacy and interest also have an effect on students. Students taught by teachers with positive self-efficacy and high interest in teaching, display a higher interest in the subject, perform better in different subjects, and also have higher self-efficacy beliefs (Baumert, \& Kunter, 2006; Long, \& Woolfolk Hoy, 2006; Baumert et al., 2011).

\section{Motivation of Civic Education Teachers}

In the context of civic education, Weißeno and colleagues adjusted the model of Baumert and Kunter (2006) to reflect values tied specifically to civic education. Their assessment found that there are differences between teachers-in-training and teachers who had been in the field for a few years. Teachers-in-training display lower interest in the instruction of civic education than their more experienced colleagues. Furthermore, male civic education teachers' interest in teaching this subject is higher than the interest of female civic education teachers (Oberle et al., 2013). Näther and Merkens found that only 7 percent of German primary school teachers surveyed, indicate interest in further professional training in civics (Näther, \& Merkens, 2012), though it should be noted that Näther and Merkens only considered the epistemological dimension. Additionally, Manzel found that the self-efficacy of civic education students influences their career choice (Manzel, 2013). Results of the study by Oberle, Weschenfelder and Weißeno demonstrate that the self-efficacy of civic education teachers-in-training is mainly positive (Oberle et al., 2013).

\section{Defining Sustainable Development}

To put the study at hand into an appropriate didactical framework, an important model of key concepts and subject concepts of politics (Weißeno, Detjen, Juchler, Massing, \& Richter, 2010) used within German Civic Education should be considered. This model reflects additional developments within German Civic Education didactics since 2004 (Weißeno, Detjen, Juchler, Massing, \& Richter, 2010), and aligns with the focus on professional competencies (Weinert, 2001). A content-related proficiency within civic education is of critical importance for content standards, which offer a primer for students summarising the expectations for their participation in the course. With this framework in mind, the researchers (Weißeno et al., 2010) created this common and theoretical model, with a focus on politics as a core theme within the larger subject of social studies. The introduced focus is reached by key and subject concepts. Key concepts mean core principles within the domain of a certain subject, and within the domain of politics three key concepts and several concrete subject concepts can be distinguished. These subject concepts serve to put the key concepts into concrete terms. The following figure serves to illustrate the given model (Figure 1).

This introduced structure was adopted from natural science and aims to systematise competencies in order to help teachers clarify and plan lesson units. (Weißeno, Detjen, Juchler, Massing, \& Richter, 2010). 


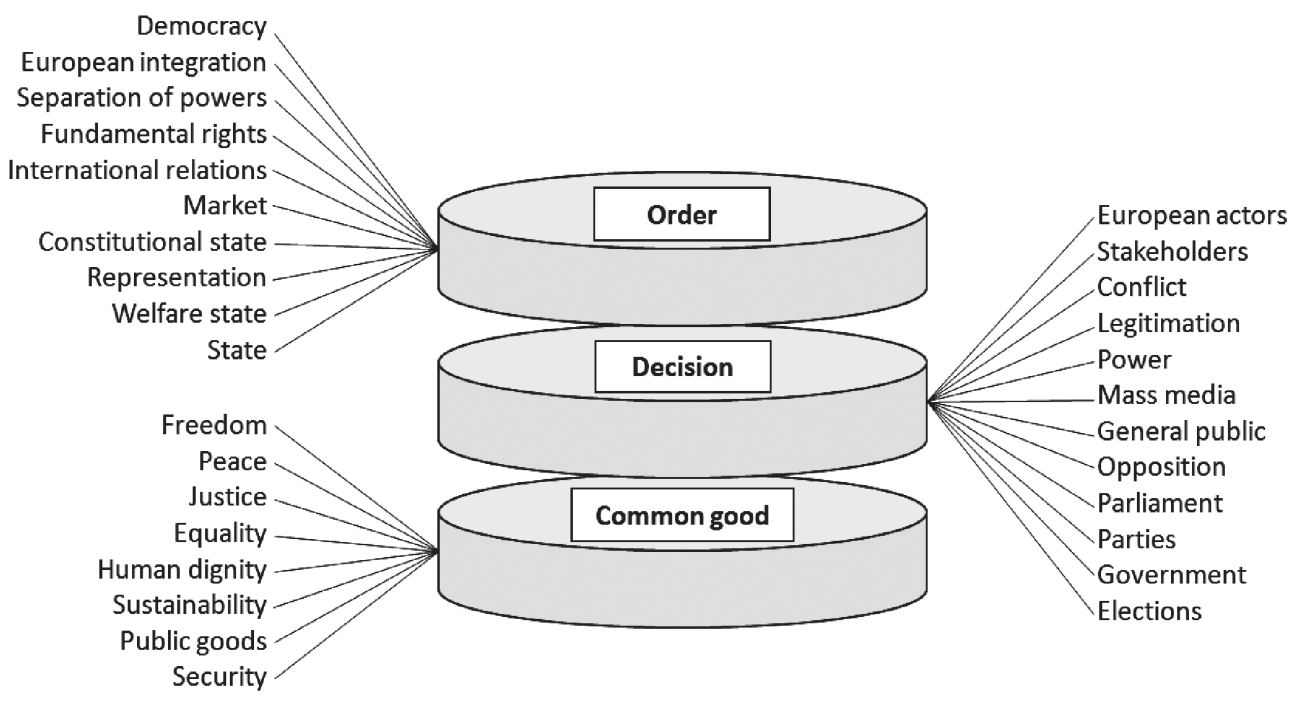

Figure 1. Model of key and subject concepts of politics (Weißeno, Detjen, Juchler, Massing, \& Richter, 2010, p. 12) (translated version)

Sustainability is one concrete concept within the general key concept of common good, in addition to freedom, peace, justice, equality, human dignity, security and public goods. The term 'sustainability' contains a cosmopolitan view of the key concept, common good. To discuss the term sustainability and sustainable development would go beyond the scope of this paper. However, one crucial distinction must be drawn between sustainability as a state or end of a process and sustainable development as the process of social change (Grunwald, \& Kopfmüller, 2012, p. 11). In this context, the authors suggest referring to the well-known definition from the Brundtland report concerning sustainable development:

"Sustainable development is development that meets the needs of the present without compromising the ability of future generations to meet their own needs. It contains within it two key concepts:

- the concept of 'needs', in particular the essential needs of the world's poor, to which overriding priority should be given; and

- the idea of limitations imposed by the state of technology and social organization on the environment's ability to meet present and future needs." (United Nations, 1987)

One can further state that "Sustainable development [...] is an inclusive concept that applies to all countries of the world; [...]. It is central to all efforts towards the human shaping of the world through globalization" (Brunold, 2015).

Certain misconceptions exist when talking about sustainability. The concept of sustainability can often be found in combination with or even to say restriction to environmental issues (Rieß, 2010). Aspects of economic, social or political issues remain unconsidered in this context. Even more, crucial values and patterns are not featured within this analysis, which must consider local, national, international and global perspectives (Ohlmeier, \& Brunold, 2015). 
The holistic approach takes three dimensions into account, includes good governance, and can only be successful by implementing a stronger role of education (Brunold, 2015). As future consumers and participating citizens, students must be empowered to reach this aim (Ohlmeier, 2013). In this respect, teachers are important change agents and must help develop students' knowledge and ability to cope with these important tasks. The study at hand serves to investigate future teachers' likelihood to fulfil their role as successful drivers for sustainable development education.

\section{Research Questions and Survey Design}

In summary, the findings show that motivation plays an important role in teacher proficiency. There are already perceptions on motivation of civic education teachers. Generally, these perceptions cover a wide range of topics. Specific information about teachers' motivation in teaching topics concerning sustainable development is rare. There are studies in which the researchers assessed the interest and self-efficacy of teachers-intraining (Filho, 2012), the study of Redman for example mentioned the general lack of deep knowledge regarding sustainability (Redman, 2013) and the study presented by Kukk and Talts (Kukk, \& Talts, 2007) refers in general to teachers' self-assessment of professional skills. But these studies do not reflect the political perspective of sustainable development.

Therefore, the following research questions arise:

1. How do self-efficacy beliefs of teachers-in-training in the context of sustainable development differ from their self-efficacy beliefs in other topics?

2. How does the inherent interest in the field of sustainable development differ from their self-efficacy beliefs in other topics?

108 civic education teachers-in-training at the University of Augsburg participated in the survey. The teachers-in-training were studying to become primary teachers $(\mathrm{N}=39)$, teachers at Mittelschule $(\mathrm{N}=57)$ or at grammar school $(\mathrm{N}=12)$ and were attending 10 different courses at the University of Augsburg. Their average age was 25 $(\mathrm{M}=24.54 ; \mathrm{SD}=3.83)$. 76 of the interviewees were female, 32 were male.

While the teachers-in-training who are studying to become teachers at a grammar school chose civic education as one general subject (107 ECTS-points), the University of Augsburg offers multiple opportunities for primary teachers to pursue civic education topics in their academic course load. In the context of a subject-related degree program, it is possible to choose civic education as a main subject (69 ECTS-points) or as a subject of didactics (11 ECTS-points). Most of the primary teachers wanting to be placed at Mittelschule $(62.22 \%)$ encounter civic education during their studies as a subject of didactics.

The data were collected by a questionnaire, and answers were scaled to help respondents subjectively rate their own self-efficacy beliefs related to sustainable development according to the questionnaire for teacher self-efficacy by Schwarzer \& Schmitz (1999). In order to compare sustainability with other subject concepts, the teachers were asked to assess their beliefs according to the key concept common goods, which is part of the model of key and subject concepts of politics (Weißeno et al., 2010, p. 12). The scales for self-efficacy beliefs in the particular subjects' concepts with an internal consistency from $r=.66$ to $r=.83$ are satisfactory results. 
The second question of the study concerns the assessment of teachers' interest in sustainability compared to other subject concepts. For this analysis, we focused on the interest in teaching. Basis for these scales were the questionnaires of Franz (2008), Kleickmann (2008) and Krapp et al. (1993). The Cornbachs Alpha from $r=.65$ to $r=.82$ is satisfactory. The answer format of the scales for both constructs has four stages $(0=$ strongly agree to $3=$ strongly disagree). To compare the self-efficacy beliefs and interests of the teachers-in-training, we calculated one sample-t-Test with the program SPSS 23, which facilitates statistical analysis.

\section{Research Findings}

Regarding the means you can see that there is only one subject concept that civic education teacher-in-training feel less self-efficient in than sustainability (see Figure 1). If you count all of the other subject concepts combined and compare this with the subject concept of sustainability, the evaluation of the questionnaires shows, that, on average, the self-efficacy beliefs of the surveyed teachers-in-training related to sustainability $(\mathrm{M}=.66, \mathrm{SD}=.18)$ is lower than their average self-efficacy beliefs in all other subject concepts of common goods $(\mathrm{M}=.75, \mathrm{SD}=.13)$. This difference, .09 , is significant $\mathrm{t}(107)=\mathrm{p}<.05$, and represents a medium-sized effect, $\mathrm{d}=.65$ (see Table 1 ).

Although the resultant interest of teachers-in-training in teaching sustainability $(\mathrm{M}=.75, \mathrm{SD}=.17)$ is lower than their average interest in all other key concepts of common goods $(\mathrm{M}=.81)$, this difference, .01. $\mathrm{BCa}$ is not significant $\mathrm{t}(107)=\mathrm{p}<.05$.

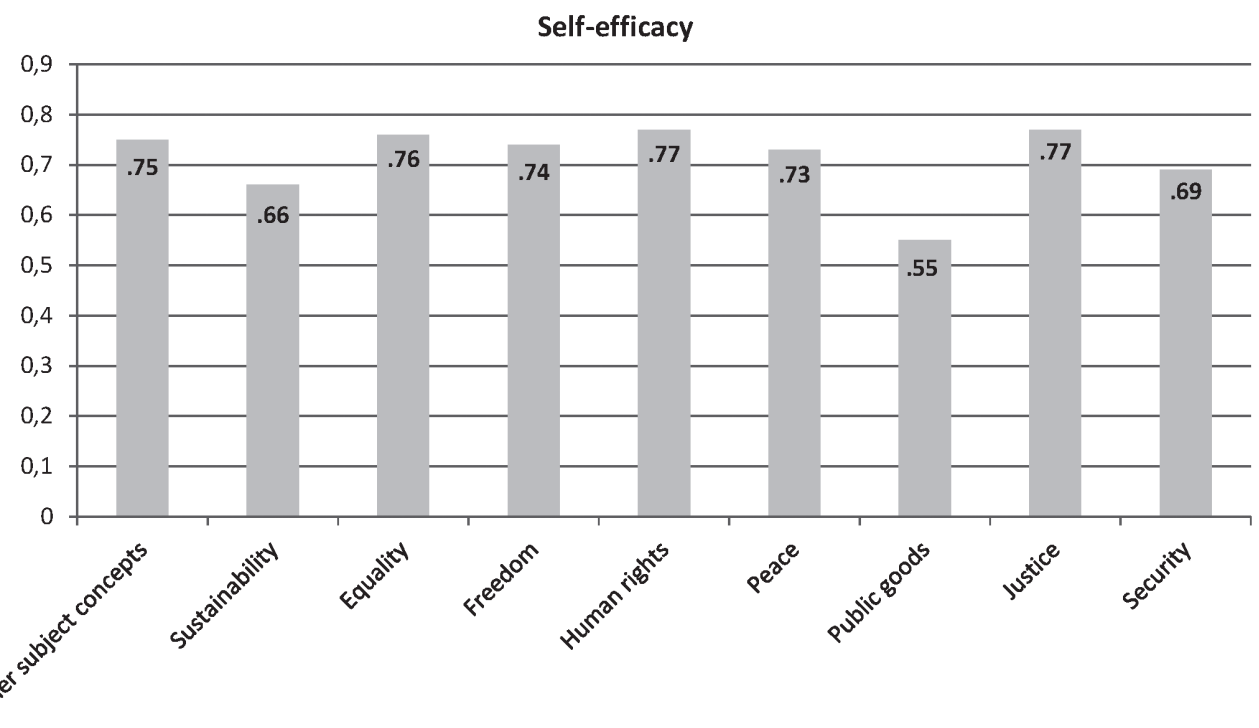

Figure 2. Civic education students' self-efficacy concerning the subject concepts of the key concept common good

Note: other subjects = mean of equality, freedom, human rights, peace, public goods, justice and security 


\section{Interest}

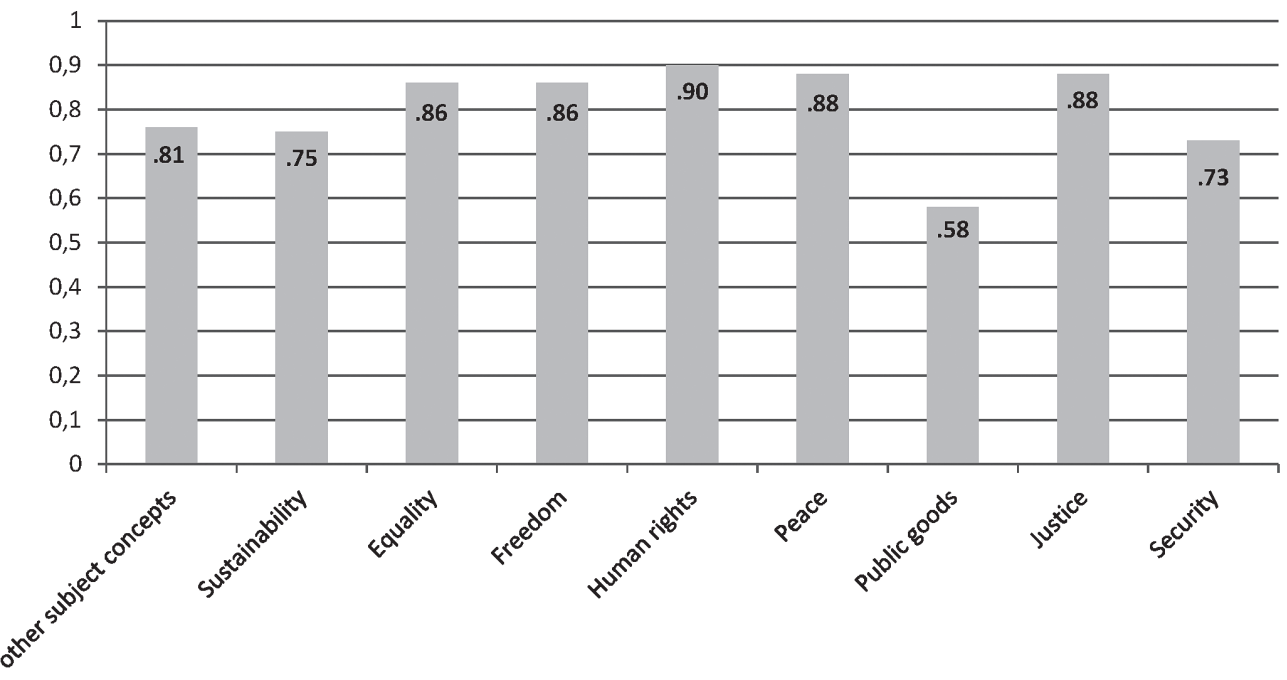

Figure 3. Civic education students' interest concerning the subject concepts of the key concept common good

Note: other subjects = mean of equality, freedom, human rights, peace, public goods, justice and security

\section{Discussion}

The presented results are part of a study that is subject to methodological restrictions (convenience sampling, low number of cases). Despite the given limitations, the data provide insights as it relates to teachers' interest and self-efficacy beliefs concerning the subject concept sustainability. In the context of this study, we found that the surveyed teachers-in-training at the University of Augsburg believe they can teach most of the other subject concepts of the key concept common goods better than the key concept sustainability. This difference is significant, and leads us to ask why their self-efficacy in this subject concept is comparatively low. One possibility is that teachers-in-training spend insufficient time on topics concerning sustainable development during their academic studies. It is therefore conceivable that teachers' level of self-efficacy rises when they spend more time with topics concerning sustainable development. As the range of concrete topics covering sustainable development is very big, a discussion of appropriate concrete topics would go beyond the scope of this paper. Reichhart showed in her study with primary teachers-in-training that it is possible to change their self-efficacy to teach political issues at primary school by attending a university class. The interviewed teachersin-training at the University of Augsburg participated in a course with twelve sessions (3 ECTS-Points) and showed even six month after they finished the course significant higher self-efficacy to teach political issues than they did at the beginning of the course. The concept of the course was based on findings of reflexive and explorative learning (Reichhart, 2017). Further research would be needed to find out if self-efficacy of teachersin-training can also be changed if the narrower concept of sustainable development is concerned, which is part of the model of political competence (Weißeno, 2010). 
Although the teachers-in-trainings' interest in teaching sustainable development related topics is not very high compared to other subject concepts like justice or human rights, the comparison with all other subject concepts is not significant. This shows that the interviewed teachers-in-training are on the one hand interested in teaching sustainable development but on the other hand - this shows their significant low self-efficacy don't feel confident teaching sustainable development. Because both competencies teachers' interest and teacher's self-efficacy - are important parts of teachers' professional competency and affect students' learning (Baumert, \& Kunter, 2006) the results of this study suggest that it is more urgent to concentrate on the development of teacher-intrainings' self-efficacy concerning sustainability than on their interest in sustainability. If these results can be replicated with a larger sample and additional measurements of teacher proficiency, they could indicate a need to adapt teacher education. Furthermore, it would be interesting to evaluate which components best represent sustainable development according to Civic Education teachers.

\section{References}

Baumert, J., \& Kunter, M. (2006). Stichwort: Professionelle Kompetenz von Lehrkräften. [Keyword: teachers' professional competency]. Zeitschrift für Erziehungswissenschaft [Journal for Educational Sciences] 9(4), 469-520.

Baumert, J., Blum, W., Kunter, M., \& Neubrand, M. (Ed.) (2011). Professionelle Kompetenz von Lehrkräften. Ergebnisse des Forschungsprogramms COACTIV. [Teachers' professional competency. Results of the research program COACTIV]. Münster: Waxmann.

Brunold, A. (2015). Civic education for sustainable development and its consequences for German civic education didactics and curricula of higher education. Discourse and Communication for Sustainable 6, 30-49.

Caprara, G. V., Barbaranelli, C., Steca, P., \& Malone, P. S. (2006). Teachers' selfefficacy beliefs as determinants of job satisfaction and students' academic achievement. A study at the school level. Journal of School Psychology 44, 473-490.

Eren, A. (2012). Prospective teachers' interest in teaching, professional plans about teaching and career choice satisfaction. A relevant framework? Australian Journal of Education 56(3), 303-318.

Filho, L. W. (Ed.) (2012). Sustainable development at universities: new horizons. [...papers submitted to the World Symposium on Sustainable Development at Universities (WSSD-U-2012), Rio de Janeiro, Brazil June 5-6, 2012]. World Symposium on Sustainable Development at Universities; WSSD-U-2012. Frankfurt.: Lang.

Franz, U. (2008). Lehrer- und Unterrichtsvariablen im naturwissenschaftlichen Sachunterricht. Eine empirische Studie zum Wissenserwerb und zur Interessenentwicklung in der dritten Jahrgangsstufe. [Teachers- and lessons variables in science education. An empirical study of knowledge acquisition and evolution of interests in the third grade level of German primary school]. Bad Heilbrunn: Klinkhardt.

Gebauer, M. M. (2013). Determinanten der Selbstwirksamkeitsüberzengung von Lehrenden. Schulischer Berufsalltag an Gymnasien und Hauptschulen. [Teachers's self-efficacy determinants. Educational daily professional life in grammar and general schools].Wiesbaden: Springer. 
Grunwald, A., \& Kopfmüller, J. (2012). Nachhaltigkeit. [Sustainability]. Frankfurt am Main: Campus Verlag.

Kleickmann, T. (2008). Zusammenhänge fachspezifischer Vorstellungen von Grundschullehrkräften zum Lehren und Lernen mit Fortschritten von Schülerinnen und Schülern im konzeptuellen naturwissenschaftlichen Verständnis. Dissertation. [Connection between primary teachers' subject specific perceptions of learning and teaching with students' progress in conceptional science understanding. Dissertation] Munster: Westfälischen Wilhelms-Universität Münster.

Krapp, A., Schiefele, U., Wild, K.P., \& Winteler, A. (1993). Der Fragebogen zum Studieninteresse. [Questionnaire for interests of students]. Diagnostika 39(4), 335-351.

Kukk, A., \& Talts, L. (2007). Teachers' self-assessment of their professional skills according to the teachers' professional standard. Journal of Teacher Education for Sustainability 8, 14-24.

Long, J. F., \& Woolfolk H. A. (2006). Interested instructors. A composite portrait of individual differences and effectiveness. Teaching and Teacher Education 22, 303314.

Manzel, S. (2013). Performanz im Politikunterricht - Theorieansätze und Entwicklungstrends zum professionellen Lehrer/-innenwissen und Unterrichtshandeln. [Performance in civic education - theoretical approaches and development trends concerning professional teachers' knowledge and lessons action]. In K.-P.Hufer, \& D. Richter (Ed.). Politische Bildung als Profession. Verständnisse und Forschungen: Perspektiven politischer Bildung. [Civic education as profession. Understanding and research: Perspectives of civic education] (203-216) Bonn: Bundeszentrale für polit. Bildung 1355.

Näther, T., \& Merkens, H. (2012). Auswertung der Befragung zu den Fortbildungspräferenzen von Grundschullehrenden. [Evaluation of interviews concerning primary school teachers' preferences for training courses]. In H. Merkens (Ed.). Technikinteresse von Grundschullehrkräften. [Primary school teachers' interest in technology], 50, 38-74.

Oberle, M., Weschenfelder, E., \& Weißeno, G. (2013). Motivationale Orientierungen angehender und praktizierender Politiklehrkräfte. [Motivational orientation of teachers to-be and practising teachers]. In A. Besand (Ed.). Lehrer-und Schülerforschung in der politischen Bildung. [Research of teachers and students in the field of civic education], 12, 55-67.

Ohlmeier, B. (2013). Civic education for sustainable development. Discourse and Communication for Sustainable Education 4, 5-22.

Ohlmeier, B., \& Brunold, A. (2015). Politische Bildung für nachhaltige Entwicklung. Eine Evaluationsstudie. [Civic education for sustainable development. An evaluation study]. Wiesbaden: Springer Verlag.

Redman, E. (2013). Opportunities and challenges for integrating sustainability education into K-12 schools: case study Phoenix. Journal of Teacher Education for Sustainability 5(2), 5-24.

Reichhart, B. (2017). Motivationale Orientierungen von Grundschullehramtsstudierenden im Bereich der politischen Bildung [Motivational constructs of primary school teachers-in-training in the field of civic education]. In H. Giest, A. Hartinger, \& S. Tänzer (Ed.) Vielperspektivität im Sachunterricht [Multiple perspectives of General studies], 217-224. 
Retelsdorf, J., Butler, R., Streblow, L., \& Schiefele, U. (2010). Teachers' goal orientations for teaching. Associations with instructional practices, interest in teaching and burnout. Learning and Instruction 20, 30-46.

Rieß, W. (2010). Bildung für nachhaltige Entwicklung. Theoretische Analysen und empirische Studien.[Education for sustainable education. Theoretical analysis and empirical studies]. Münster: Waxman Verlag.

Schiefele, H. (1974). Lernmotivation und Motivlernen. [Learning motivation and motif learning], München: Ehrenwirth.

Schwarzer, R., \& Jerusalem, M. (2002). Das Konzept der Selbstwirksamkeit. [The concept of self-efficacy]. Zeitschrift für Pädagogik [Journal for Education], 44, 44, $28-53$.

Schwarzer, R., \& Schmitz, G. (1999). Skala zur Lehrer-Selbstwirksamkeitserwartung (WIRKLEHR) [Scale for teachers' self-efficacy expectation (WIRKLEHR). In R. Schwarzer, \& M Jerusalem (Ed.). Skalen zur Erfassung von Lehrer- und Schülermerkmalen. Dokumentation der psychometrischen Verfahren im Rahmen der wissenschaftlichen Begleitung des Modellversuchs Selbstwirksame Schulen. [Scales for acquisition of teachers' and students' features. Documentation of psychometric procedures within the framework of scientific support self-efficacy school pilot project.], 60-62.

United Nations. (1987). Our common future: Report of the world commission on environment (A/42/427). Retrieved from http://www.un-documents.net/ocf-02.htm

Weinert, F. E. (2001). Concept of competence - A conceptual clarification. In D. Rychen, \& L. Salyanik, (Ed.). Defining and selecting key competencies, 45-65.

Weißeno, G., Detjen, J., Juchler, I., Massing, P., \& Richter, D. (2010). Konzepte der Politik-ein Kompetenzmodel. [Concepts of politics. A competency model]. Bonn: Bundeszentrale für politische Bildung.

Correspondence concerning this paper should be addressed to Katharina Hiller, Civic Education and Civic Education Didactics, University of Augsburg, Germany. Email: katharina.hiller@phil.uni-augsburg.de; Barbara Reichhart, Chair of Primary School Pedagogic and Didactics, University of Augsburg, Germany. Email: barbara.reichhart@phil.uni-augsburg.de 